\title{
Devonian plutons in southeastern Cape Breton Island, Nova Scotia
}

\author{
Sandra M. Barr and Alan S. Macdonald \\ Department of Geology, Acadia University, Wolfville, Nova Scotia BOP 1XO, Canada
}

Date Received September 28, 1991

Date Accepted January 29, 1992

\begin{abstract}
Four granitic plutons and a suite of granitic dykes of Devonian age occur in the Mira (Avalon) Terrane of southeastern Cape Breton Island. Granodiorite gradational to granite in the Lower St. Esprit pluton is chemically distinct from and unlikely to be genetically linked to comparable units in the other plutons. The Salmon River pluton consists of highly evolved rhyolite porphyry and is also not likely to be genetically linked to the other units. In contrast, the Gillis Mountain and Deep Cove plutons and the Blue Mountain dykes are interpreted to be co-genetic and possibly co-magmatic on the basis of chemical continuity among their units, which range in composition from quartz monzodiorite to granite and rhyolite porphyry. They have I-type petrographic and chemical features, whereas the Lower St. Esprit has some M-type characteristics and the Salmon River rhyolite porphyry appears transitional between felsic I-type and A-type granites. $\mathrm{Cu}-\mathrm{Mo}$ mineralization is associated with the Gillis Mountain pluton, and polymetallic $\mathrm{Cu}-\mathrm{Mo}-\mathrm{Pb}-\mathrm{Zn}-\mathrm{Bi}-\mathrm{Ag}$ mineralization with greisen zones in the Deep Cove pluton and with skarn in the Blue Mountain contact metamorphic aureole. Minor $\mathrm{Cu}-\mathrm{Zn}$ mineralization occurs adjacent to the Lower St. Esprit pluton, although a definite genetic relationship with the pluton has not been established. Trace $\mathrm{Pb}$ mineralization has been reported from the Salmon River pluton. The origin of these Devonian plutons is uncertain, but is postulated to have been linked to regional strike-slip faulting and extension.
\end{abstract}

Quatre plutons granitiques et une suite de dykes granitiques d'âge Dévonien gisent dans le terrain de Mira (Avalon) du sud-est de l'lle-du-Cap-Breton. La granodiorite, en transition avec du granite, du pluton de Lower StEsprit est chimiquement distincte et n'est probablement pas reliée génétiquement aux unités comparables des autres plutons. Le pluton de la rivière Salmon consiste en une rhyolite porphyrique très évoluée et n'est probablement pas relié génétiquement aux autres unités. En contraste, les plutons des monts Gillis et de l'anse Deep ainsi que les dykes du mont Blue sont interprétés comme étant cogénétiques et possiblement comagmatiques, sur la base de la continuité chimique entre leurs unités, qui vont des monzodiorites quartzifères aux granites et aux rhyolites porphyriques. Ces roches intrusives ont des caractéristiques pétrographiques et chimiques de granites de type I tandis que le pluton de Lower $\mathrm{St}$-Esprit a quelques caractéristiques de type $\mathrm{M}$ et que la rhyolite porphyrique de la rivière $\mathrm{Salmon}$ semble être transitionnelle entre les granites felsiques de type I et ceux de type A. De la minéralisation en Cu-Mo est associée au pluton du mont Gillis, de la minéralisation polymétallique en $\mathrm{Cu}-\mathrm{Mo}-\mathrm{Pb}-\mathrm{Zn}-\mathrm{Bi}-\mathrm{Ag}$ avec des zones de greisen se retrouve dans le pluton de l'anse Deep et il y a des skarns dans l'auréole métamorphique du mont Blue. Il y a des occurences mineures de minéralisation en $\mathrm{Cu}-\mathrm{Zn}$ près du pluton de Lower St-Esprit bien qu'un lien génétique définitif avec le pluton n'ait pas été établi. Des traces de minéralisation en $\mathrm{Pb}$ sont mentionnées pour le pluton de la rivière Salmon. L'origine de ces plutons dévoniens est incertaine mais on suppose qu'elle est reliée aux failles de décrochement et d'extension régionales.

[Traduit par le journal]

\section{INTRODUCTION}

Early workers assumed that granitic plutons in southeastern Cape Breton Island are of Devonian age like those in southern Nova Scotia (e.g., Weeks, 1954). However, radiometric dating (e.g., Cormier, 1972, 1979; Barr et al., 1984, 1991) subsequently has shown that many of the plutons are late Precambrian in age. Devonian intrusions (Fig. 1) include

\footnotetext{
*The term rhyolite is used in this paper to describe fine-grained, probably hypabyssal, intrusive rocks that have textures more typical of extrusive rocks (e.g., spherulitic) rather than the granular textures more typical of plutonic rocks. The term porphyry is used informally for rocks in which phenocrysts are a major component (generally more than $40 \%$ ) and occur in a fine-grained groundmass.
}

only the Lower St. Esprit pluton (Barr et al., 1989, 1991), the Gillis Mountain pluton (O'Beirne, 1979; Barr and O'Beime, 1979; Barr and Pride, 1986), the Deep Cove pluton (Barr et al., 1982; Dennis, 1988; Macdonald, 1989), the Blue Mountain rhyolite porphyry ${ }^{\circ}$ dyke suite (Macdonald and Barr, in press), and the Salmon River pluton (Barr et al., 1984; McMullin, 1984). These Devonian intrusions are of particular interest because all appear to be directly or indirectly associated with mineralization, most importantly with $\mathrm{Cu}$ Mo-dominant, polymetallic deposits (Barr and Macdonald, 1985). The purpose of this paper is to compare and contrast various geological features and petrochemical characteristics of these plutons and to compare them to established granitoid types. Detailed descriptions and interpretations of 


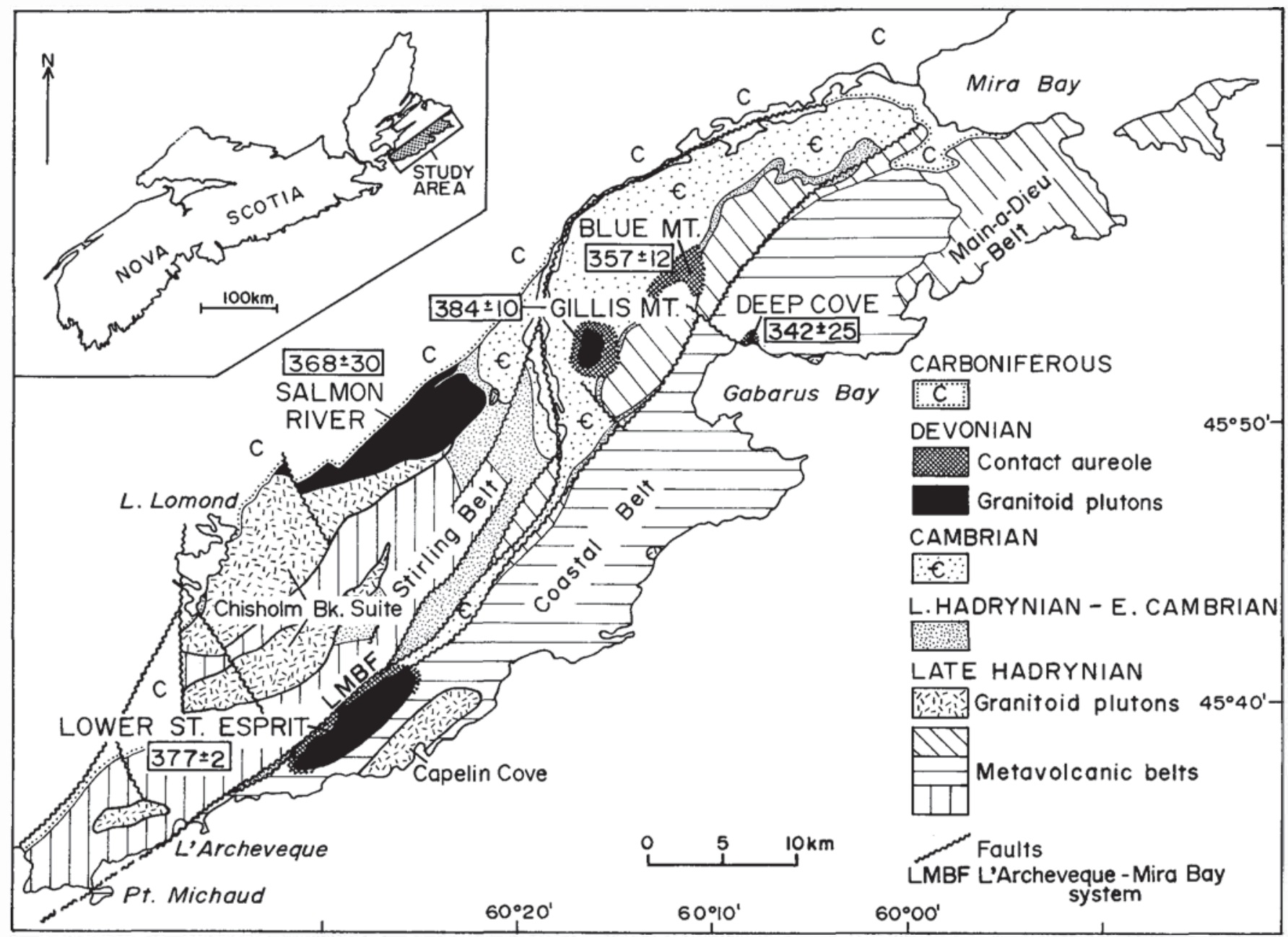

Fig. 1. Generalized geology and distribution of Devonian granitic plutons and associated contact aureoles in southeastern Cape Breton Island (after Barr et al., 1989, 1992).

individual plutons, with the exception of Lower St. Esprit, have been presented previously in the references cited above, but this paper provides the first overview of all the plutons as a group. To facilitate assessment of the overall similarities and differences among the plutons, major features are summarized in Table 1.

\section{Field Relations}

The Devonian plutons are located in the southeastern part of the Mira Terrane (Barr and Raeside, 1989). They are on both sides of the L'Archeveque - Mira Bay fault system that separates Late Hadrynian metavolcanic and metasedimentary rocks of the Stirling belt from those of the Coastal and Main-à-Dieu belts (Barr et al., 1988, 1989, 1991), and occur in both Precambrian and Cambrian host rocks (Fig. 1). Contacts with the host rocks are generally discordant, and contact metamorphic aureoles are well developed.

The Lower St. Esprit pluton is located close to the L'Archeveque - Mira Bay fault and is elongate parallel to the fault, but does not appear to have been deformed by it. The pluton is poorly exposed, with an estimated surface area of approximately $20 \mathrm{~km}^{2}$. It was formerly included as part of the Late Hadrynian Capelin Cove pluton (O'Reilly, 1977; Keppie, 1979), but is now known to be a separate pluton of different composition, as well as age (Barr et al., 1989, 1991). It intruded Late Hadrynian basaltic flows and flow-breccias and intermediate crystal-lithic tuffs of the Coastal belt and Late Hadrynian to Cambrian clastic sedimentary rocks (Fig. 1). A contact metamorphic aureole is developed along the northwestern margin of the pluton; its presence on other margins of the pluton cannot be confirmed because of lack of exposure.

The Gillis Mountain pluton intruded shale, siltstone, and sandstone of Early to Middle Cambrian age (Fig. 1). Contact metamorphism near the pluton produced cordierite-biotite hornfels and biotite-quartz granofels. The contact metamorphic mineral assemblages, together with petrographic features of the pluton (see below), suggest that the pluton was emplaced at a shallow depth (O'Beirne, 1979). Xenoliths of the host rocks are common in the pluton near its margins.

The Deep Cove pluton, located on the north shore of Gabarus Bay (Fig. 1), is sub-elliptical in shape, elongate north-south, and has a surface area of less than $0.1 \mathrm{~km}^{2}$. It 
Table 1. Summary of features of Devonian plutons in southeastem Cape Breton Island.

\begin{tabular}{|c|c|c|c|c|c|}
\hline Size & $20 \mathrm{~km}^{2}$ & $6 \mathrm{~km}^{2}$ & $0.1 \mathrm{~km}^{2}$ & unexposed & $60 \mathrm{~km}^{2}$ \\
\hline Shape & elongate & elliptical & elliptical & unexposed & laccolith \\
\hline Host & $\begin{array}{l}\text { Coastal belt } \\
\text { (Late Hadrynian- } \\
\text { Cambrian volcanic } \\
\text { and sedimentary rocks }\end{array}$ & $\begin{array}{l}\text { Cambrian } \\
\text { sedimentary rocks }\end{array}$ & $\begin{array}{l}\text { Coastsl belt } \\
\text { (Late Hadrynian } \\
\text { volcanic rocks) }\end{array}$ & $\begin{array}{l}\text { Cambrian } \\
\text { sedimentary rocks }\end{array}$ & $\begin{array}{l}\text { Stirling belt } \\
\text { (Late Hadrynian-Early } \\
\text { Cambrian plutonic and } \\
\text { sedimentary rocks) }\end{array}$ \\
\hline $\begin{array}{l}\text { Contact } \\
\text { Aureole }\end{array}$ & biotite hornfels & $\begin{array}{l}\text { cordierite-biotite } \\
\text { homfels }\end{array}$ & homfels & $\begin{array}{l}\text { cordierite-biotite } \\
\text { hornfels/granofels }\end{array}$ & not evident \\
\hline Age* & $377 \pm 2 \mathrm{Ma}$ & $384 \pm 10 \mathrm{Ma}$ & $(342 \pm 25 \mathrm{Ma})$ & $(357 \pm 12 \mathrm{Ma})$ & $(368 \pm 30 \mathrm{Ma})$ \\
\hline $\begin{array}{l}\text { Main } \\
\text { Units }\end{array}$ & $\begin{array}{l}\text { granodiorite/ } \\
\text { granite }\end{array}$ & $\begin{array}{l}\text { quartz monzodiorite } \\
\text { porphyritic granite } \\
\text { fine-grained granite }\end{array}$ & $\begin{array}{l}\text { porphyritic } \\
\text { granite }\end{array}$ & unexposed & rhyolite porphyry \\
\hline $\begin{array}{l}\text { Mafic } \\
\text { Minerals }\end{array}$ & $\begin{array}{l}\text { homblende } \\
\text { + biotite }\end{array}$ & $\begin{array}{l}\text { homblende + biotite } \\
\text { or biotite alone }\end{array}$ & biotite & biotite & biotite \\
\hline $\begin{array}{l}\text { Mineral- } \\
\text { ization }\end{array}$ & $\begin{array}{l}\text { Cu-Zn-pyrite } \\
\text { in host rocks; } \\
\text { disseminations } \\
\text { and veinlets }\end{array}$ & $\begin{array}{l}\text { Cu-Mo-pyrite in } \\
\text { pluton and host; } \\
\text { disseminations } \\
\text { and veinlets }\end{array}$ & $\begin{array}{l}\text { Cu-Mo-pyrite in } \\
\text { pluton and host; } \\
\mathrm{Zn-Pb-Bi-Ag} \mathrm{in} \\
\text { greisen; dissem., } \\
\text { and veinlets }\end{array}$ & $\begin{array}{l}\mathrm{Cu}-\mathrm{Mo}-\mathrm{Co}-\mathrm{Bi}-\mathrm{Ag} \text { in } \\
\text { skam; } \mathrm{Zn}-\mathrm{Pb} \text { in hfs; } \\
\text { replacements, dissem., } \\
\text { and veinlets }\end{array}$ & $\begin{array}{l}\text { rare } \mathrm{Pb} \text { in pluton; } \\
\text { veinlets }\end{array}$ \\
\hline $\begin{array}{l}\text { Chemical } \\
\text { Affinity }\end{array}$ & $\begin{array}{l}\text { I-type transitional } \\
\text { to M-type (?) }\end{array}$ & I-type & I-type & I-type & $\begin{array}{l}\text { I-type transitional } \\
\text { to A-type }\end{array}$ \\
\hline
\end{tabular}

-Less reliable numbers in brackets (see text for discussion)

intruded and metamorphosed tuffs and flows of the Coastal belt. Associated porphyry dykes are found mainly in coastal exposures south and southeast of the stock, within a contact metamorphic aureole which extends 100 to $200 \mathrm{~m}$ from the pluton (Ervine, 1981; Dennis, 1988).

No pluton is exposed in the Blue Mountain area, located between Gillis Mountain and Deep Cove (Fig. 1), but an arcuate zone of hornfels and skarn with a surface area of about $4 \mathrm{~km}^{2}$ is interpreted to be a contact metamorphic aureole caused by an underlying pluton. The contact aureole has been intruded by rhyolite porphyry dykes up to $12 \mathrm{~m}$ in thickness that are interpreted to be related to the unexposed pluton. The aureole rocks are cordierite-biotite hornfels, biotite-quartz granofels, and nodular calc-silicate hornfels with anthophyllite-grossularite skarn layers which are the contact metamorphosed, and in part metasomatized, equivalents of Lower to Middle Cambrian shale, siltstone, sandstone, and limestone (Barr et al., 1992).

The Salmon River rhyolite porphyry is located west of the Mira River and north of the Stirling belt of Late Hadrynian rocks (Fig. 1). It intruded granodiorite of the Chisholm Brook Suite and Upper Hadrynian - Lower Cambrian clastic sedimentary rocks (Fig. 1). The pluton is larger, with a surface area of about $60 \mathrm{~km}^{2}$, and more irregular in shape than the other Devonian plutons in southeastern Cape Breton Island. Locally concordant intrusive contacts and satellitic sills suggest that it may be laccolithic or sheet-like in form (McMullin, 1984). Although contact metamorphic effects are not obvious in the granodioritic or coarse clastic host rocks, Late Precambrian detrital muscovite in the clastic rocks has undergone Silurian or younger partial argon loss ( $P$. Reynolds, personal communication, 1991).

\section{Age}

Although various evidence (summarized below) indicates that all these plutons are Devonian, only the Lower St. Esprit pluton has been precisely dated by the U-Pb method. It yielded a mid-Devonian age of $377 \pm 2 \mathrm{Ma}$ (Barr et al., 1991; M.L. Bevier, personal communication, 1991). The age of the Gillis Mountain pluton is considered to be reasonably well constrained at $384 \pm 10 \mathrm{Ma}$, based on a 12-point $\mathrm{Rb}-\mathrm{Sr}$ isochron with an initial ${ }^{86} \mathrm{Sr}{ }^{87} \mathrm{Sr}$ ratio of 0.704 (Cormier, 1979). Within error limits, the Rb-Sr age is the same as the U$\mathrm{Pb}$ age of the Lower St. Esprit pluton.

A whole rock - mineral $\mathrm{Rb}-\mathrm{Sr}$ isochron indicates an age of $342 \pm 25 \mathrm{Ma}$ for the Deep Cove pluton (Cormier, 1972; Keppie and Smith, 1978). However, petrochemical similarities to the Gillis Mountain pluton (O'Beirne, 1979; Dennis, 1988) suggest that the Deep Cove pluton may be older than this isochron indicates and similar in age to the Gillis Mountain pluton (ca. $384 \mathrm{Ma}$ ). 
A K-Ar biotite date of $357 \pm 12 \mathrm{Ma}$ from hornfels in the Blue Mountain area is interpreted to be a cooling age for the contact metamorphic aureole (Macdonald and Barr, in press). It seems likely that the inferred underlying pluton is somewhat older, and hence, probably similar in age to the Gillis Mountain and Deep Cove plutons.

The age of the Salmon River rhyolite porphyry is indicated by an Rb-Sr isochron at $368 \pm 30 \mathrm{Ma}$ (Barr et al., 1984). $\mathrm{U}-\mathrm{Pb}$ dating of zircon from the porphyry was attempted but yielded only sparse xenocrystic zircons of Archean age (Doig et al., 1990).

In summary, although apparent ages span a wide range from early Devonian to early Carboniferous, a mid- to late Devonian age is postulated for all five plutons.

\section{Petrography}

The Lower St. Esprit pluton is composed of granite transitional to granodiorite. Major minerals are quartz, plagioclase, and perthitic orthoclase in approximately equal proportions, and 10 to $15 \%$ hornblende and biotite. Accessory phases include magnetite, sphene, apatite, and zircon. Texture is typically medium-grained and hypidiomorphic granular, but locally orthoclase forms scattered phenocrysts up to $2 \mathrm{~cm}$ in length. Alteration consists mainly of saussurite and sericite in feldspars, and chlorite in biotite.

Unlike the other plutons, the Gillis Mountain pluton is composite, and comprised of mappable units of quartz monzodiorite, porphyritic granite, and fine-grained granite (terminology of Barr and O'Beirne, 1979), as well as dykes of granitic porphyry, fine-grained granite, and aplite that occur in the quartz monzodiorite and porphyritic granite units. The quartz monzodiorite consists of fine- to medium-grained hypidiomorphic granular plagioclase, quartz, alkali feldspar, and 15 to $20 \%$ mafic minerals including biotite, amphibole, and rare pyroxene. The porphyritic granite varies widely in texture from hiatal porphyritic through seriate porphyritic to medium-grained equigranular but is mineralogically uniform, and consists of a groundmass of plagioclase, alkali feldspar, quartz, and up to $12 \%$ biotite and amphibole. Phenocrysts are mainly of plagioclase, up to $2 \mathrm{~cm}$ in length. The alkali feldspar appears to be sanidine, based on its low $2 \mathrm{~V}$ (O'Beirne, 1979), evidence for rapid cooling at shallow depth. The fine-grained granite unit is mineralogically similar to the porphyritic granite, but is fine- to medium-grained and contains only sparse phenocrysts of plagioclase. Accessory phases in all three units include magnetite, apatite, zircon, and sphene \pm pyrite. The various granitic dykes associated with the pluton are mainly compositionally similar to and inferred to be co-genetic with the main granitic units (O'Beirne, 1979; Barr and O'Beime, 1979). All the units show variable amounts of alteration, mainly saussuritization of plagioclase and chloritization of amphibole and biotite.

The Deep Cove pluton is composed of seriate porphyritic granite with associated granite and granodiorite/tonalite porphyry dykes and aplite dykes (Dennis, 1988). Major minerals are plagioclase, sanidine, quartz, and biotite (typically $5-10 \%$ ), with accessory magnetite, apatite, and zircon. The granitic porphyry dykes are mineralogically similar but are finer grained, contain fewer and less strongly zoned plagioclase phenocrysts, and have locally developed granophyric textures. Granodiorite/tonalite porphyry dykes are texturally similar to the granitic porphyries but contain little alkali feldspar and minor hornblende $(<1 \%)$ in addition to biotite. The aplite dykes display fine-grained quartz-feldspar intergrowth textures and contain only minor amounts of biotite. Alteration in the Deep Cove pluton varies in intensity, as described in some detail by Dennis (1988). Saussurite, sericite, and chlorite are abundant, and in more intensely altered zones, pervasive replacement of the primary minerals by these minerals as well as by quartz, clay minerals, hematite, and carbonate has occurred. The most intensely altered zones consist of quartz-sericite-pyrite greisen. No tourmaline was observed in these zones but they contain elevated boron concentrations (Dennis, 1988).

The Blue Mountain dykes are porphyritic, with phenocrysts of albitized plagioclase, quartz, and rare muscovite in an aphanitic to fine-grained, spherulitic or granophyric to allotriomorphic granular groundmass of quartz, alkali feldspar, sericite, chlorite, calcite, epidote, and pyrite. Some dykes now contain very little alkali feldspar, probably as a consequence of albitization.

The Salmon River pluton is composed of relatively uniform rhyolite porphyry (or fine-grained granite), with small areas of more mafic granophyric granite. The phenocrysts are sanidine, quartz, plagioclase and rare muscovite, and occur in a fine-grained granular groundmass of feldspar, quartz, sericite, minor chloritized biotite, and iron oxides. The feldspar phenocrysts are partly altered to saussurite and sericite.

\section{Mineralization}

The Lower St. Esprit pluton does not contain visible mineralization but minor $\mathrm{Cu}-\mathrm{Zn}$-bearing pyritic mineralization occurs adjacent to the northwestern margin of the pluton in an altered basaltic flow-breccia. Skarn-like garnet-diopside layers along fractures in these rocks were probably formed as a result of metasomatism related to the pluton and the mineralization processes.

Pyrite, chalcopyrite, and molybdenite occur as disseminations, fracture coatings, and veinlets, and in quartz veins, developed locally in all units of the Gillis Mountain pluton and to a minor extent in the adjacent hornfels, but are generally concentrated in the porphyritic granite unit and in granite porphyry dykes. The characteristics of the pluton and the associated mineralization and alteration have been suggested to indicate affinity with porphyry-type Cu-Mo deposits (Hollister et al., 1974; Kirkham and Soregaroli, 1975; O'Beirne, 1979).

Disseminated Cu-Mo mineralization occurs sporadically throughout the Deep Cove granite, and two more concentrated types of mineralization are also present, greisen-hosted 
and quartz vein-hosted. Greisen-hosted mineralization consists of the $\mathrm{Cu}-\mathrm{Mo}$ mineralization with a polymetallic $\mathrm{Zn}-\mathrm{Pb}$ $\mathrm{Bi}-\mathrm{Ag}$ sulphide-sulphosalt-telluride association occurring in seams and quartz-calcite veins within the greisen zones (Dennis, 1988). Quartz vein-hosted mineralization consists of fracture-controlled, quartz-molybdenite-pyrite veins that occur both in the pluton and in the volcanic country rocks.

Copper mineralization is associated with the Blue Mountain skarns, and is of a complex polymetallic type (Cu-MoCo-Bi-Ag) found in some calcic skarns (Einaudi et al., 1981). Chalcopyrite, pyrrhotite and arsenopyrite predominate over magnetite and are accompanied by minor amounts of molybdenite, bismuthinite, sphalerite and galena (Macdonald, 1989; Macdonald and Barr, in press).

Minor vein-type galena is the only mineralization that has been reported directly associated with the Salmon River pluton (Barr et al., 1984). Younger stratabound lead mineralization (forming the Yava deposit) occurs in Pennsylvanian sandstones on the edge of the Loch Lomond basin immediately to the west of the porphyry, and it has been suggested that erosion of the Salmon River rhyolite porphyry may have contributed lead for deposition at Yava (Sangster and Vaillancourt, 1990; Vaillancourt and Sangster, 1984). Also present in the area are stratabound deposits of celestite and minor barite within the Mississippian Windsor Group at the edge of the basin farther to the southwest (Felderhof, 1978), although their relationship, if any, to the pluton has not been investigated.

\section{Chemical Characteristics}

To facilitate chemical comparisons, average compositions for the main units of the Devonian plutons and associated dykes are compiled in Table 2, and selected chemical parameters are shown on Figures 2 to 7 . The original data have been presented elsewhere, with the exception of those for the Lower St. Esprit pluton which are given in Table 3. In each case, least altered samples without obvious sulphide phases were selected for analysis, except in the case of the Blue Mountain dykes where intense alteration and disseminated pyrite could not be avoided.

On the basis of the four samples that have been analyzed, the Lower St. Esprit pluton appears chemically homogeneous. The $\mathrm{SiO}_{2}$ content (average $68.5 \%$ ) is similar to that in the fine-grained granite unit of the Gillis Mountain pluton, but the Lower St. Esprit granite/granodiorite differs in having lower $\mathrm{FeO}(\mathrm{t})$ and $\mathrm{CaO}$, and higher $\mathrm{MgO}$ and $\mathrm{Na}_{2} \mathrm{O}$ (Table 2). These differences are reflected on the AFM diagram, where the Lower St. Esprit samples lie off the trend of the Gillis Mountain samples (Fig. 2a). Compared to Gillis Mountain samples, the Lower St. Esprit granite/granodiorite is also characterized by lower contents of $\mathrm{Rb}$ and $\mathrm{Ba}$ relative to $\mathrm{Sr}$, and appears to represent a less evolved magma (Fig. 3 ). The samples from the Lower St. Esprit pluton do not show evidence of the elevated and highly variable abundances of $\mathrm{Cu}, \mathrm{Pb}$, and/or $\mathrm{Zn}$ that characterize the other plutons (Table 2).
Chemical trends within and between the various units of the Gillis Mountain pluton (Fig. 2a,b) are consistent with a sequence of differentiation, resulting from mainly plagioclase and hornblende fractionation, from quartz monzodiorite through the granitic units to the late-stage aplitic dykes (Barr and O'Beirne, 1979; Barr and Pride, 1986). The finegrained granite unit is slightly more felsic in average composition than the porphyritic granite, and appears to be the most evolved of the main units. It is similar in composition to many of the granitic porphyry dykes, which were possibly derived from it as they occur mainly in the other two units. The Gillis Mountain pluton is interpreted to have formed by high-level intrusion of magma in a series of pulses from a deeper, evolving magma chamber (Barr and Pride, 1986).

The Deep Cove porphyritic granite has a higher silica content (average $72.3 \%$ ) than the Gillis Mountain granites (Table 2). The associated granitoid porphyry dykes show a wider range in composition than the main granite. As a group, the Deep Cove samples display trends that are generally continuous with those of the Gillis Mountain samples (Fig. $2 \mathrm{a}, \mathrm{b})$. Together with the similarities in texture and mineralization, these trends have been interpreted to indicate that the two plutons are co-genetic, or possibly co-magmatic (O'Beirne, 1979; Dennis, 1988), implying that the Deep Cove pluton may represent later, more evolved magma pulses from the same, or at least a similar, underlying magma chamber.

The Blue Mountain rhyolite porphyry dykes range in $\mathrm{SiO}_{2}$ content from 70 to $74 \%$, similar to the Deep Cove granite, although their average $\mathrm{SiO}_{2}$ content (73.9\%) is higher than in the Deep Cove granite (72.3\%). They show a similar trend on the AFM diagram, although they are generally higher in iron content (Fig. 2a). They are also similar in relative $\mathrm{Ba}-\mathrm{Rb}-\mathrm{Sr}$ abundances (Fig. 3). It seems reasonable to conclude that the Blue Mountain dykes represent the late stages of magma evolution in an underlying pluton and that the pluton was co-genetic and possibly co-magmatic with the Deep Cove and Gillis Mountain plutons.

The Salmon River rhyolite porphyry is highly felsic, with $\mathrm{SiO}_{2}$ contents ranging from 73 to $76 \%$, except in two fine-grained granite samples that have lower $\mathrm{SiO}_{2}$ contents (Fig. 2b). Most samples cluster near the $\mathrm{Na}_{2} \mathrm{O}+\mathrm{K}_{2} \mathrm{O}$ apex on the AFM diagram, in a position similar to the aplitic dykes from other plutons (Fig. 2a). The Salmon River rhyolite porphyry is characterized by high $\mathrm{Rb}$ relative to $\mathrm{Ba}$ and $\mathrm{Sr}$ values, and on a Rb-Ba-Sr plot (Fig. 3), it appears to be much more evolved than the other felsic units, except an aplite dyke from Gillis Mountain.

Rare-earth element (REE) data have been previously published from the Gillis Mountain, Deep Cove, and Salmon River plutons, and data for two samples from the Lower St. Esprit pluton are listed in Table 3. No REE data are available for the Blue Mountain dykes. The Gillis Mountain, Deep Cove, and Lower St. Esprit samples show similar chondritenormalized REE patterns, with enriched light REE, moderate to slight negative Eu anomalies, and depleted heavy REE (Fig. 4). However, the Lower St. Esprit samples show more 
Table 2. Average major and trace element compositions for each of the Devonian plutons and related dykes.

\begin{tabular}{|c|c|c|c|c|c|c|c|c|c|c|c|c|c|c|c|c|c|c|c|c|c|c|c|c|}
\hline Pluton: & \multirow{2}{*}{\multicolumn{2}{|c|}{$\begin{array}{c}\text { L. St. Esprit } \\
\text { granite/ } \\
\text { granodiorite }\end{array}$}} & \multicolumn{10}{|c|}{ Gillis Mountain } & \multicolumn{8}{|c|}{ Deep Cove } & \multirow{2}{*}{\multicolumn{2}{|c|}{$\begin{array}{l}\text { Blue Mountain } \\
\text { rhyolite } \\
\text { porphyry dykes }\end{array}$}} & \multirow{2}{*}{\multicolumn{2}{|c|}{$\begin{array}{c}\text { Salmon River } \\
\text { thyolite } \\
\text { porphyry }\end{array}$}} \\
\hline Unit: & & & \multicolumn{2}{|c|}{$\begin{array}{l}\text { quartz } \\
\text { momeodiorite }\end{array}$} & \multicolumn{2}{|c|}{$\begin{array}{l}\text { porphyritic } \\
\text { granite }\end{array}$} & \multicolumn{2}{|c|}{$\begin{array}{l}\text { fine-grained } \\
\text { granite }\end{array}$} & \multicolumn{2}{|c|}{$\begin{array}{l}\text { granite porphyry } \\
\text { dykes }\end{array}$} & \multicolumn{2}{|c|}{$\begin{array}{l}\text { aplite } \\
\text { dykes }\end{array}$} & \multicolumn{2}{|c|}{$\begin{array}{l}\text { granodiorite } \\
\text { porphyry dykes }\end{array}$} & \multicolumn{2}{|c|}{$\begin{array}{l}\text { porphyritic } \\
\text { granite }\end{array}$} & \multicolumn{2}{|c|}{$\begin{array}{l}\text { granite porphyry } \\
\text { dykes }\end{array}$} & \multicolumn{2}{|c|}{$\begin{array}{l}\text { aplite } \\
\text { dykes }\end{array}$} & & & & \\
\hline$\%$ & $\mathrm{n}=$ & $=4$ & & $=9$ & & $=28$ & & $=7$ & & $=5$ & $\mathrm{n}=$ & $=2$ & & $=4$ & & $=19$ & & $=7$ & & $=3$ & & $=11$ & & $=23$ \\
\hline $\mathrm{SiO}_{2}$ & $68.51=$ & \pm 0.70 & $60.14=$ & \pm 1.37 & 67.40 & \pm 1.10 & 68.27 & \pm 1.42 & 69.72 & \pm 0.76 & 76.16 & \pm 0.88 & 68.42 & \pm 1.15 & 72.26 & \pm 1.17 & 72.81 & \pm 0.84 & 73.33 & \pm 1.45 & 73.85 & \pm 1.02 & 74.70 & \pm 1.00 \\
\hline $\mathrm{TiO}_{2}$ & 0.42 & 0.03 & 1.39 & 0.11 & 0.62 & 0.07 & 0.62 & 0.07 & 0.41 & 0.11 & 0.01 & 0.01 & 0.56 & 0.19 & 0.37 & 0.05 & 0.38 & 0.05 & 0.45 & 0.22 & 0.47 & 0.04 & 0.08 & 0.03 \\
\hline $\mathrm{Al}_{2} \mathrm{O}_{3}$ & 15.32 & 0.17 & 16.29 & 0.73 & 15.07 & 0.64 & 14.83 & 0.29 & 14.22 & 0.72 & 12.56 & 0.71 & 14.96 & 0.69 & 14.11 & 0.47 & 13.53 & 0.23 & 13.15 & 0.12 & 13.88 & 0.28 & 13.83 & 0.50 \\
\hline $\mathrm{Fe}_{2} \mathrm{O}_{3}$ & $2.61^{t}$ & 0.22 & 1.30 & 0.37 & 1.06 & 0.44 & 0.77 & 0.26 & 0.88 & 0.44 & 0.58 & 0.00 & 0.53 & 0.28 & 0.38 & 0.11 & 0.35 & 0.11 & 0.35 & 0.20 & $2.97^{t}$ & 0.50 & 0.59 & 0.33 \\
\hline $\mathrm{FeO}$ & $\therefore$ & - & 5.82 & 0.50 & 2.66 & 0.49 & 2.85 & 0.32 & 2.00 & 0.73 & 0.29 & 0.06 & 2.62 & 0.33 & 1.23 & 0.27 & 1.29 & 0.31 & 1.22 & 0.68 & - & - & 0.56 & 0.16 \\
\hline $\mathrm{MnO}$ & 0.06 & 0.00 & 0.11 & 0.03 & 0.05 & 0.01 & 0.04 & 0.01 & 0.03 & 0.02 & 0.01 & 0.01 & 0.06 & 0.01 & 0.03 & 0.01 & 0.03 & 0.01 & 0.03 & 0.02 & 0.06 & 0.01 & 0.03 & 0.02 \\
\hline $\mathrm{MgO}$ & 2.31 & 0.46 & 2.60 & 0.34 & 1.38 & 0.17 & 1.14 & 0.15 & 0.78 & 0.33 & 0.06 & 0.01 & 1.48 & 0.33 & 1.08 & 0.17 & 1.08 & 0.14 & 0.83 & 0.29 & 0.85 & 0.12 & 0.13 & 0.07 \\
\hline $\mathrm{CaO}$ & 1.79 & 0.07 & 4.81 & 0.36 & 2.70 & 0.53 & 2.18 & 0.29 & 1.88 & 1.19 & 0.29 & 0.35 & 2.58 & 0.58 & 1.59 & 0.26 & 1.30 & 0.08 & 0.86 & 0.57 & 1.34 & 0.85 & 0.33 & 0.17 \\
\hline $\mathrm{Na}_{2} \mathrm{O}$ & 4.13 & 0.55 & 3.64 & 0.15 & 3.69 & 0.18 & 3.58 & 0.15 & 3.49 & 0.12 & 3.82 & 0.10 & 3.88 & 0.28 & 3.54 & 0.22 & 3.39 & 0.44 & 3.16 & 0.87 & 3.32 & 0.85 & 3.60 & 0.56 \\
\hline $\mathrm{K}_{2} \mathrm{O}$ & 3.72 & 0.08 & 2.28 & 0.49 & 3.53 & 0.42 & 4.01 & 0.13 & 3.72 & 0.38 & 4.41 & 0.07 & 3.04 & 1.05 & 4.12 & 0.22 & 4.29 & 0.34 & 5.26 & 1.85 & 3.13 & 1.13 & 4.80 & 0.50 \\
\hline $\mathrm{P}_{2} \mathrm{O}_{5}$ & 0.15 & 0.01 & 0.36 & 0.04 & 0.15 & 0.03 & 0.13 & 0.03 & 0.12 & 0.00 & 0.02 & 0.00 & 0.17 & 0.05 & 0.11 & 0.01 & 0.12 & 0.03 & 0.07 & 0.03 & 0.12 & 0.04 & 0.05 & 0.05 \\
\hline LOI & 1.00 & 0.34 & 1.50 & 0.45 & 1.44 & 0.38 & 1.42 & 0.28 & 2.93 & 1.16 & 1.28 & 0.06 & 1.09 & 0.35 & 0.72 & 0.25 & 0.53 & 0.21 & 0.53 & 0.40 & 2.29 & 0.40 & 0.99 & 0.46 \\
\hline ACNK & 1.09 & & 0.95 & & 1.02 & & 1.05 & & 1.08 & & 1.08 & & 1.08 & & 1.07 & & 1.04 & & 1.06 & & 1.23 & & 1.18 & \\
\hline ppm & & & & & & & & & & & & & & & & & & & & & & & & \\
\hline $\mathrm{Ba}$ & 999 & \pm 60 & 720 & \pm 85 & 748 & \pm 54 & 843 & \pm 32 & 921 & \pm 94 & 162 & 1 & 1027 & \pm 313 & 692 & \pm 95 & 726 & \pm 104 & 3035 & \pm 3921 & 442 & \pm 89 & 124 & \pm 201 \\
\hline $\mathrm{Rb}$ & 83 & 5 & 92 & 12 & 147 & 14 & 146 & 4 & 177 & 48 & 326 & 45 & 143 & 54 & 205 & 13 & 208 & 19 & 142 & 20 & 137 & 29 & 210 & 55 \\
\hline Sr & 773 & 22 & 446 & 23 & 304 & 21 & 254 & 13 & 193 & 12 & 68 & 7 & 298 & 76 & 195 & 35 & 169 & 27 & 216 & 104 & 135 & 42 & 25 & 16 \\
\hline$Y$ & 11 & 2 & 29 & 2 & 25 & 2 & 32 & 1 & 37 & $-*$ & 51 & $*$ & 26 & 4 & 26 & 2 & 26 & 3 & 21 & 9 & 33 & 2 & 20 & 5 \\
\hline$Z_{x}$ & 145 & 9 & 237 & 14 & 173 & 11 & 231 & 6 & 291 & 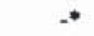 & 93 & -* & 196 & 23 & 166 & 12 & 172 & 16 & 130 & 60 & 200 & 7 & 72 & 7 \\
\hline $\mathrm{Nb}$ & 9 & 1 & 16 & 1 & 14 & 1 & 17 & 0 & 27 & $-*$ & 59 & $-*$ & 15 & 2 & 14 & 1 & 15 & 1 & 11 & 5 & 19 & 1 & 19 & 7 \\
\hline $\mathrm{Cu}$ & 6 & 2 & 129 & 203 & 83 & 96 & 33 & 1 & 43 & 18 & 48 & 8 & 59 & 59 & 11 & 9 & 54 & 53 & 51 & 43 & 41 & 27 & 5 & 1 \\
\hline $\mathrm{Pb}$ & 2 & 1 & 10 & 8 & 115 & 286 & 87 & 98 & 136 & 225 & 82 & 19 & 81 & 97 & 158 & 412 & 226 & 494 & 311 & 448 & 477 & 996 & 137 & 452 \\
\hline $\mathrm{Zn}$ & 49 & 8 & 94 & 19 & 163 & 215 & 313 & 249 & 532 & 934 & 38 & 4 & 209 & 168 & 333 & 611 & 697 & 1444 & 905 & 1048 & 4007 & 7645 & 35 & 25 \\
\hline $\mathrm{Ni}$ & 24 & 4 & 27 & 4 & 15 & 4 & 15 & 0 & 11 & 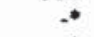 & 7 & -* & 15 & 4 & 18 & 4 & 16 & 3 & 13 & 3 & 9 & 6 & 5 & 1 \\
\hline $\mathrm{Cr}$ & 35 & 11 & 50 & 5 & 44 & 7 & 48 & 4 & 26 & -* & 27 & $-*$ & 34 & 3 & 30 & 3 & 31 & 5 & 26 & 3 & 32 & 6 & 10 & 9 \\
\hline v & 46 & 4 & 153 & 17 & 57 & 8 & 53 & 8 & 15 & $-*$ & $<5$ & $-*$ & 58 & 14 & 30 & 4 & 29 & 5 & 25 & 5 & 32 & 3 & 5 & 0 \\
\hline $\mathrm{Ga}$ & 20 & 2 & 21 & 2 & 18 & 1 & 17 & 0 & 22 & $-*$ & 20 & $-*$ & 19 & 2 & 17 & 3 & 16 & 2 & 17 & 2 & 17 & 2 & 19 & 2 \\
\hline Th & $<2$ & - & 11 & 2 & 14 & 3 & 13 & 4 & 12 & $\left({ }^{*} n=1\right)$ & 22 & $\left({ }^{*} n=1\right)$ & 21 & 4 & 27 & 10 & 30 & 11 & 36 & 12 & 32 & 15 & 26 & 11 \\
\hline
\end{tabular}

$t=$ total $\mathrm{Fe}$ as $\mathrm{Fe}_{2} \mathrm{O}_{3}$

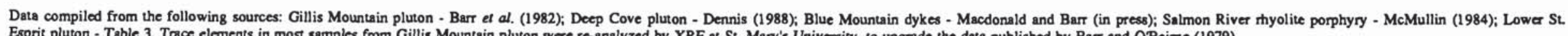
Esprit pluton - Table 3. Trace elements in most samples from Gillis Mountain pluton were re-analyzed by XRF at St. Mary's University, wo upgrade the data published by Barr and OBeime (1979). 
Table 3. Major, trace, and rare-earth element composition of the Lower St. Esprit pluton.

\begin{tabular}{|c|c|c|c|c|}
\hline Sample No. & FS-578 & FS-507 & FS-563 & FS-514 \\
\hline \multicolumn{5}{|l|}{$\%$} \\
\hline $\mathrm{SiO}_{2}$ & 67.70 & 68.30 & 68.65 & 69.38 \\
\hline $\mathrm{TiO}_{2}$ & 0.46 & 0.42 & 0.41 & 0.40 \\
\hline $\mathrm{Al}_{2} \mathrm{O}_{3}$ & 15.48 & 15.41 & 15.45 & 15.19 \\
\hline $\mathrm{Fe}_{2} \mathrm{O}_{3} \mathrm{~T}$ & 2.92 & 2.63 & 2.43 & 2.46 \\
\hline $\mathrm{MnO}$ & 0.06 & 0.06 & 0.06 & 0.05 \\
\hline $\mathrm{MgO}$ & 2.23 & 2.03 & 2.00 & 2.98 \\
\hline $\mathrm{CaO}$ & 1.73 & 1.87 & 1.81 & 1.74 \\
\hline $\mathrm{Na}_{2} \mathrm{O}$ & 3.86 & 4.04 & 4.93 & 3.69 \\
\hline $\mathrm{K}_{2} \mathrm{O}$ & 3.60 & 3.74 & 3.73 & 3.80 \\
\hline $\mathrm{P}_{2} \mathrm{O}_{5}$ & 0.16 & 0.15 & 0.15 & 0.14 \\
\hline LOI & 1.40 & 0.90 & 1.10 & 0.60 \\
\hline Total & 99.60 & 99.28 & 100.72 & 100.43 \\
\hline \multicolumn{5}{|l|}{$\mathrm{ppm}$} \\
\hline $\mathrm{Ba}$ & 1048 & 943 & 951 & 1055 \\
\hline$R b$ & 81 & 91 & 81 & 80 \\
\hline Sr & 748 & 767 & 795 & 744 \\
\hline $\mathrm{Y}$ & 11 & 11 & 13 & 9 \\
\hline $\mathrm{Zr}$ & 154 & 147 & 147 & 133 \\
\hline $\mathrm{Nb}$ & 9 & 8 & 9 & 9 \\
\hline $\mathrm{Cu}$ & 7 & 8 & 7 & 3 \\
\hline $\mathrm{Pb}$ & $<1$ & 3 & 1 & $<1$ \\
\hline $\mathrm{Zn}$ & 50 & 53 & 54 & 37 \\
\hline $\mathrm{Ni}$ & 28 & 26 & 21 & 21 \\
\hline $\mathrm{Cr}_{\mathrm{r}}$ & 47 & 20 & 36 & 35 \\
\hline $\mathrm{v}$ & 51 & 46 & 47 & 41 \\
\hline Ga & 19 & 18 & 20 & 22 \\
\hline Th & $<2$ & $<2$ & $<2$ & $<2$ \\
\hline \multicolumn{5}{|c|}{ Rare-earth elements } \\
\hline $\mathrm{La}$ & & 28.99 & & 30.84 \\
\hline $\mathrm{Ce}$ & & 56.12 & & 52.94 \\
\hline Pr & & 6.16 & & 5.75 \\
\hline Nd & & 20.65 & & 18.82 \\
\hline Sm & & 3.22 & & 2.91 \\
\hline $\mathrm{Eu}$ & & 0.51 & & 0.44 \\
\hline Gd & & 2.24 & & 2.16 \\
\hline $\mathrm{Tb}$ & & 0.26 & & 0.26 \\
\hline Dy & & 1.43 & & 1.34 \\
\hline Ho & & 0.25 & & 0.25 \\
\hline Er & & 0.71 & & 0.67 \\
\hline $\mathrm{Yb}$ & & 0.60 & & 0.60 \\
\hline Lu & & 0.10 & & 0.09 \\
\hline
\end{tabular}

Analyses by X-Ray Fluorescence at the Nova Scotia Regional Geochemical Facility, St. Mary's University. Rare-earth element analyses were done by ICP.MS at Memorial University of Newfoundland (Jenner et al., 1990). $\mathrm{Fe}_{2} \mathrm{O}_{3}{ }^{\mathrm{T}}=$ total iron expressed as $\mathrm{Fe}_{2} \mathrm{O}_{3}$.

depletion in the heavy REE than the other plutons. The Gillis Mountain and Deep Cove REE patterns have been interpreted to result from fractionation of plagioclase and hornblende (Barr and Pride, 1986; Dennis, 1988). Samples from the Salmon River rhyolite porphyry display very different REE patterns that are less smooth, concave-upward, and less enriched in light REE, and that have strongly negative Eu anomalies. These patterns have been interpreted to indicate minimum melts from a source with abundant plagioclase and amphibole (McMullin, 1984). REE-bearing minerals such as zircon may have been residual in the source, which could also explain the origin of the low zirconium contents (average 72 $\mathrm{ppm}$ ) in the rhyolite porphyry (Table 2).

Most of the analyzed samples from all five areas are peraluminous, with molecular $\mathrm{A} / \mathrm{CNK}$ ratios $>1$ (Table 2;
Fig. 5). Some of the spread in $\mathrm{A} / \mathrm{CNK}$ ratios within units may be due to alteration; for example, the three samples from the Blue Mountain dykes that have particularly high A/CNK ratios also have very low $\mathrm{K}_{2} \mathrm{O}$ contents, apparently as a result of albitization (Macdonald and Barr, in press). However, much of the variation within individual units is probably caused by variations in the proportion of feldspar phenocrysts in the samples. The fact that the majority of samples from all these intrusions have $\mathrm{A} / \mathrm{CNK}$ more than one indicates that the peraluminous characteristics were determined mainly by igneous processes, such as hornblende fractionation (Cawthorne et al., 1976). This interpretation is supported by the tendency for the average $\mathrm{A} / \mathrm{CNK}$ ratio to increase with increasing $\mathrm{SiO}_{2}$ content (Table 2; Fig. 5).

\section{Petrochemical Affinities}

The presence of hornblende in some units, absence of magmatic muscovite or other highly aluminous minerals other than biotite, and abundance of magnetite as an accessory phase suggest that the plutons have I-type affinities. Although many samples have A/CNK more than 1.1 (Fig. 5), a feature generally considered to be characteristic of S-type granites (e.g., Chappell and White, 1974; White and Chappell, 1983), metaluminous I-type magmas can also evolve to peraluminous compositions (Cawthorne et al., 1976).

Overall, the Gillis Mountain, Deep Cove, and Blue Mountain suites are similar to the average I-type or felsic Itype granite (Fig. 6), although average $\mathrm{Ni}, \mathrm{Cu}, \mathrm{Pb}$, and $\mathrm{Zn}$ contents are much higher, as might be expected in mineralized intrusions (even if mineralized samples were avoided in the selection of samples for analysis). The A/CNK ratio is more than in the average I-type or felsic I-type for the appropriate $\mathrm{SiO}_{2}$ content, but generally less than in the average S-type or felsic S-type granite (Fig. 5).

In contrast, the chemical patterns of the Lower St. Esprit granite/granodiorite and Salmon River rhyolite porphyry are quite different from the other plutons. The Lower St. Esprit pluton has high $\mathrm{Sr}$ and low $\mathrm{Rb}, \mathrm{Y}, \mathrm{Th}$, and $\mathrm{Pb}$ contents (Fig. 6). The pattern has some similarities to that for average $\mathrm{M}$ type granite, although the high $\mathrm{Nb}$ content in Lower St. Esprit pluton is not compatible with this affinity. Overall, it is likely that the pluton is a more primitive (less evolved) I-type. The Salmon River rhyolite porphyry has a chemical pattern that is similar to the felsic I-type granite pattern but with more depletion in $\mathrm{Ba}, \mathrm{Sr}, \mathrm{Y}, \mathrm{Zr} \mathrm{Ti}, \mathrm{V}$, and $\mathrm{Ni}$ (Fig. 6). Its pattern resembles that for the average A-type granite, except for the low contents of $\mathrm{Y}, \mathrm{Zr}$, and $\mathrm{Nb}$ (Fig. 6) and higher $\mathrm{A} / \mathrm{CNK}$ (Fig. 5). The Devonian Ackley Granite in Newfoundland (Tuach et al., 1986; Tuach, 1987; Kontak et al., 1988) has an average chemical pattern similar to that of the Salmon River rhyolite porphyry (Fig. 6).

On the plot of $\mathrm{Zr}$ against $\mathrm{Ga} / \mathrm{Al}$ ratio, most samples from the Lower St. Esprit, Gillis Mountain, Deep Cove, and Blue Mountain intrusions plot in, but near the edge of, the field of M-, I-, and S-type granites (Fig. 7a). However, more than half of the Salmon River samples plot in the A-type granite field, 

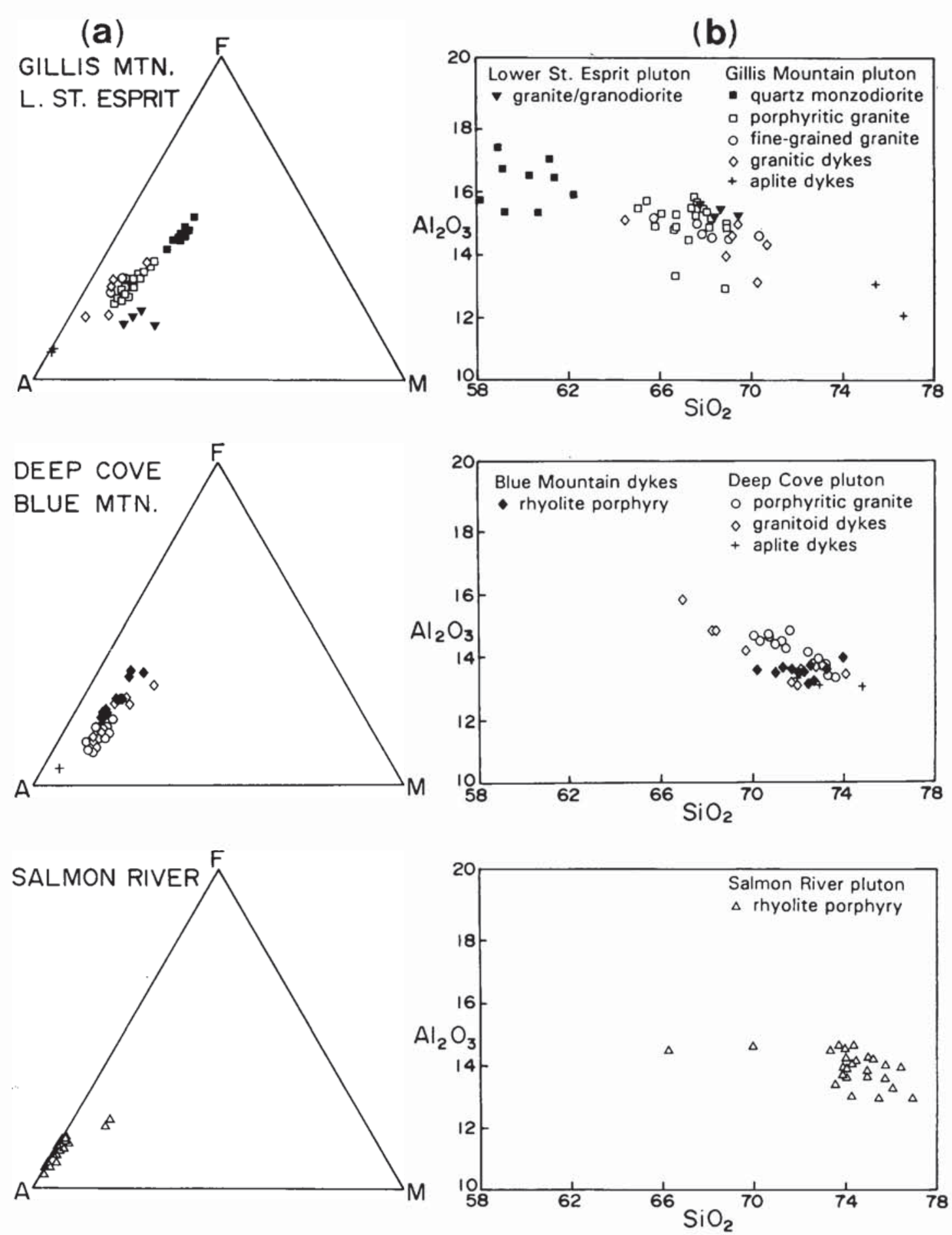

Fig. 2. Plots of (a) $\mathrm{Na}_{2} \mathrm{O}+\mathrm{K}_{2} \mathrm{O}(\mathrm{A}), \mathrm{FeO}(\mathrm{t})(\mathrm{F})$, and $\mathrm{MgO}(\mathrm{M})$ and (b) $\mathrm{Al}_{2} \mathrm{O}_{3}$ versus $\mathrm{SiO}_{2}$ (wt. \%) for the Lower St. Esprit and Gillis Mountain plutons (top), Deep Cove pluton and Blue Mountain dykes (centre), and Salmon River pluton (bottom). Data from Table 3 for the Lower St. Esprit pluton and from sources cited in the text for the other plutons.

although at much lower $\mathrm{Zr}$ content than the average A-type granite or the average Ackley Granite.

\section{Tectonic Setting}

The Devonian plutons were previously described as occurring in an arcuate, easterly trending zone transverse to the main structural trends in southeastern Cape Breton Island (Barr and Macdonald, 1985; Macdonald and Barr, in press) and hence possibly parallel to segments of major faults in the Mira River and Mira Bay area to the north (Gibling et al., 1987). Due to recognition of the Lower St. Esprit pluton, this simple transverse pattern is no longer valid and the distribution of the plutons appears to be related more broadly to the 

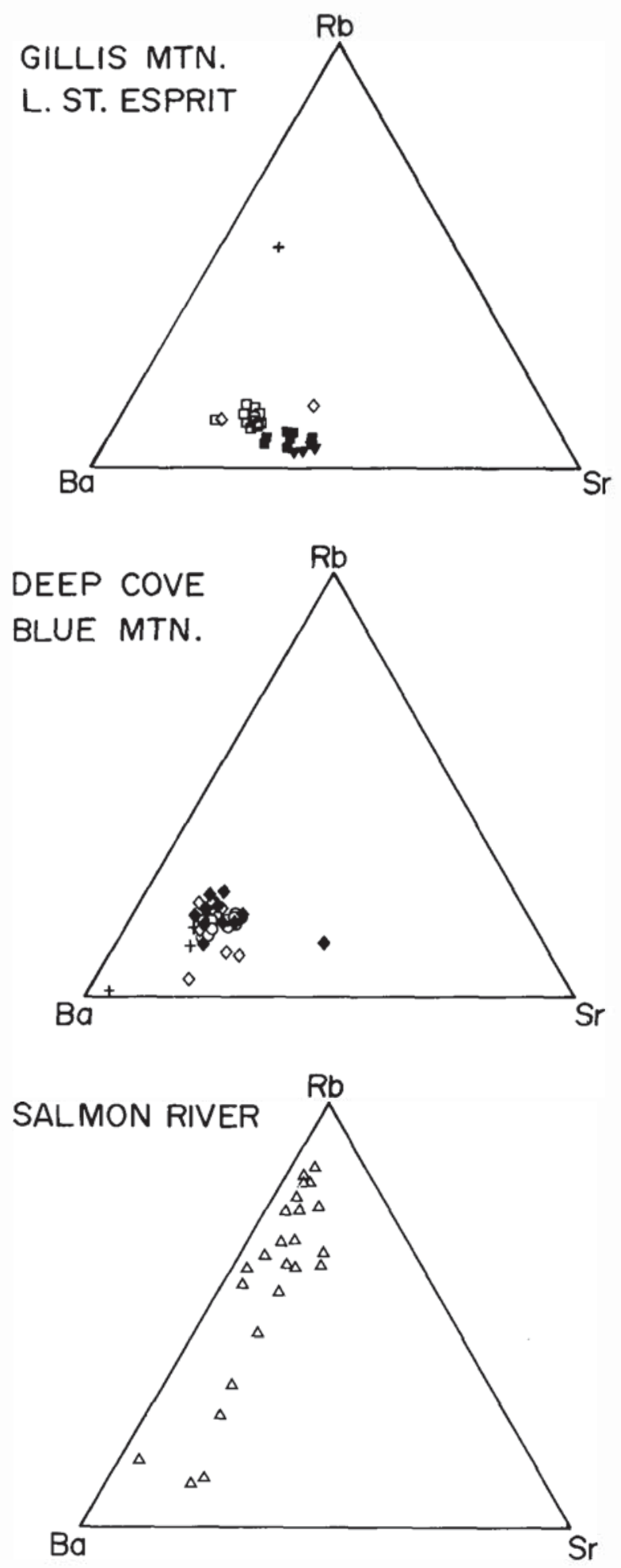

Fig. 3. Plots of Ba-Rb-Sr for the Devonian plutons. Data from Table 3 for the Lower St. Esprit pluton and from sources cited in the text for the other plutons. Symbols as in Figure 2.

northeast-trending L'Archeveque - Mira Bay fault system (Fig. 1). However, the lack of deformational features in any of these intrusions, especially the Lower St. Esprit pluton located close to the fault system, suggests that their emplace-
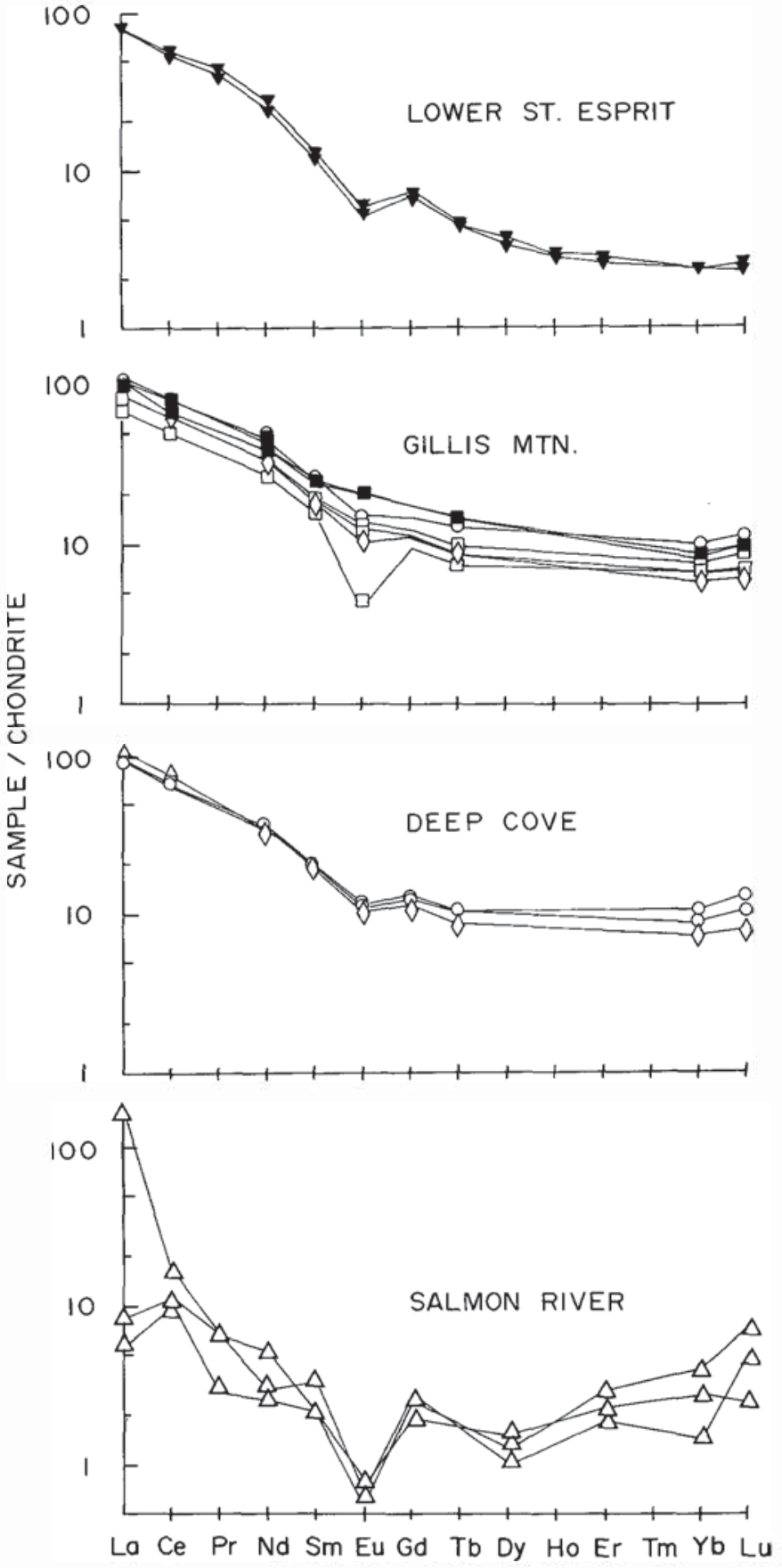

Fig. 4. Chondrite-normalized REE patterns for the Devonian plutons. Chondrite normalizing values from Evenson et al. (1978). Data from sources cited in text and Table 3. Symbols as in Figure 2.

ment post-dated faulting, and the role, if any, of faults in pluton genesis and emplacement is unclear.

Devonian tectonic models for southeastern Cape Breton Island are not well constrained because of the absence of Devonian units other than the plutons. Their I-type petrochemical features suggest that the plutons may have formed in a subduction-related setting (e.g., Pitcher, 1987). This interpretation is supported by the tectonic setting discrimination diagram of Pearce et al. (1984), on which the samples 
GILLIS MTN., L.ST. ESPRIT

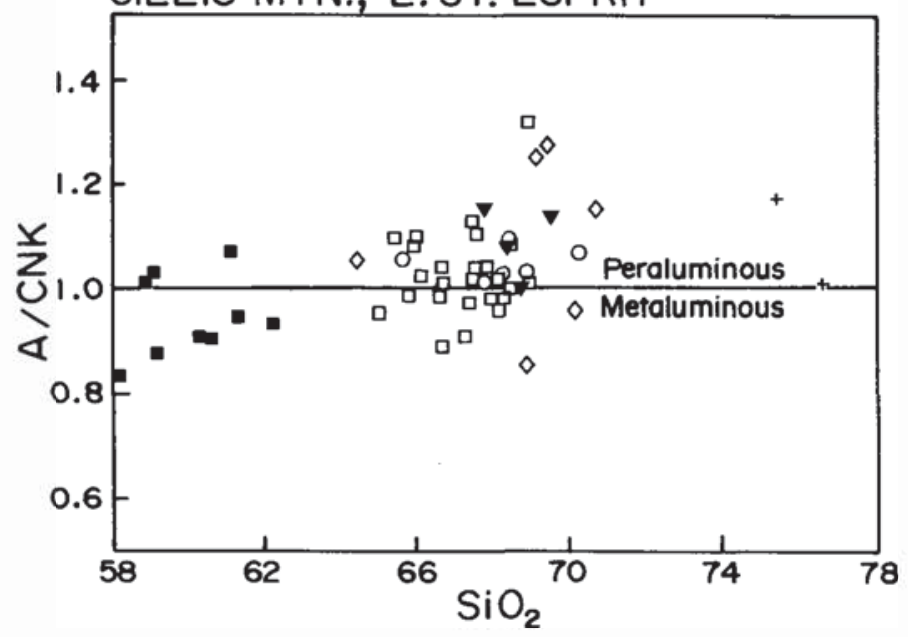

DEEP COVE, BLUE MTN.

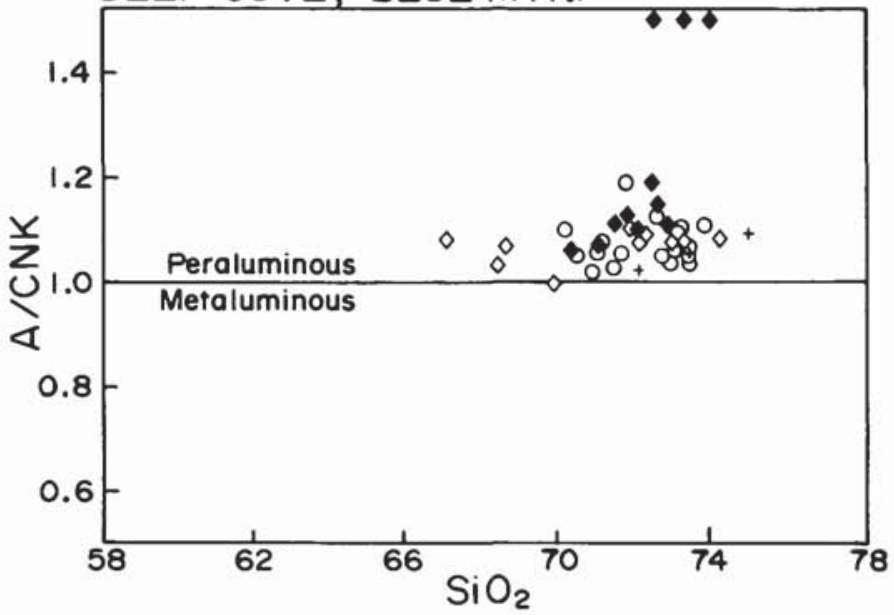

SALMON RIVER

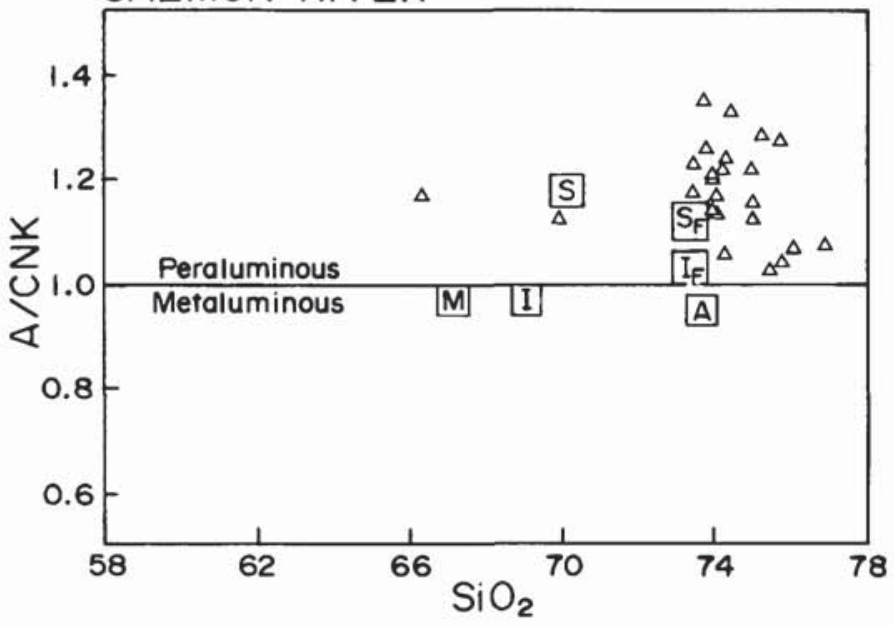

Fig. 5. Plots of $\mathrm{A} / \mathrm{CNK}$ (molecular $\mathrm{Al}_{2} \mathrm{O}_{3} / \mathrm{CaO}+\mathrm{Na}_{2} \mathrm{O}+\mathrm{K}_{2} \mathrm{O}$ ) versus $\mathrm{SiO}_{2}$ (wt. \%) for the Devonian plutons. Data from Table 3 for the Lower St. Esprit pluton and from sources cited in the text for the other plutons. Average granite compositions from Whalen $e t$ al. (1987) are shown on the Salmon River plot (M - M-type, I - Itype, I - felsic I-type, S - S-type, S, - felsic S-type, A - A-type). Other symbols as in Figure 2.

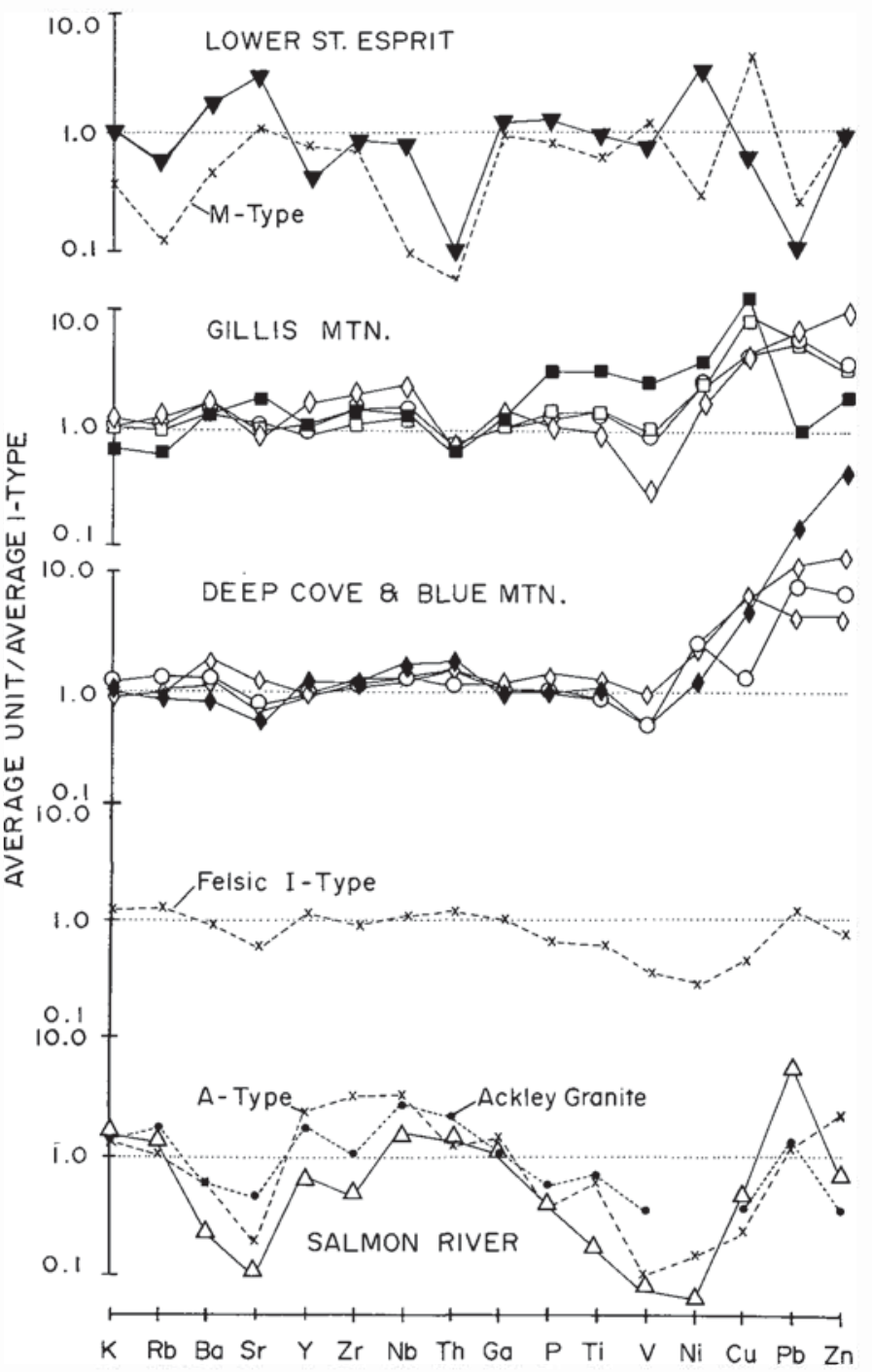

Fig. 6. Comparison of average minor/trace element compositions of the Devonian plutons with average granite types of Whalen et al. (1987) and the average Ackley Granite from Tuach et al. (1986). All average analyses are normalized against the average Itype granite of Whalen et al. (1987).

plot in the field for volcanic-arc granites (Fig. 7b), although close to the boundaries with the fields for within-plate granites or collisional granites. However, no other evidence for Devonian subduction has been recognized, and regional models for the Devonian in southeastern Cape Breton Island, and elsewhere in the northern Appalachian Orogen (e.g., Keppie, 1989; Stockmal et al., 1990) indicate that the area was undergoing transcurrent and/or thrust faulting during the final stages of terrane amalgamation. Hence, in terms of granite emplacement, the tectonic setting was likely to have been within-plate and anorogenic, as is typically characterized by A-type granites (Pitcher, 1987; Whalen et al., 1987).

It may be that in this case, pluton characteristics are controlled more by the nature of the source rocks than by the tectonic regime. The Gillis Mountain, Deep Cove, Blue 

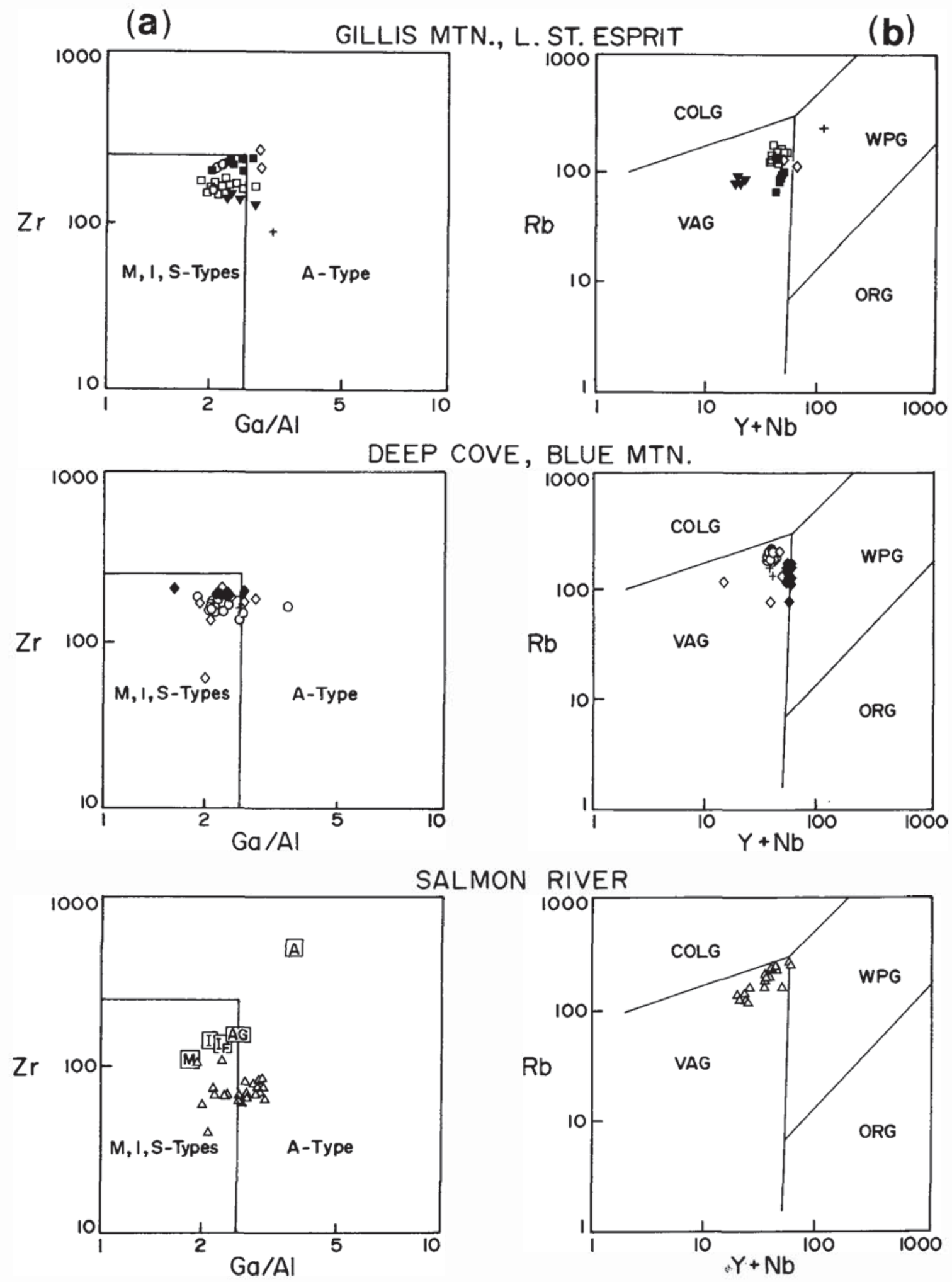

Fig. 7. Plots of (a) $\mathrm{Zr}$ versus $\mathrm{Ga} / \mathrm{Al}$ and (b) $\mathrm{Rb}$ versus $(\mathrm{Y}+\mathrm{Nb}$ ) for the Devonian plutons. Data from Table 3 for the Lower $\mathrm{St}$. Esprit pluton and from sources cited in the text for the other plutons. Average granite compositions from Whalen et al. (1987) are shown for comparison on the Salmon River plot (M - M-type, I - I-type, I, felsic I-type, A - A-type). The average Ackley Granite from Tuach et al. (1986) is AG. Other symbols as in Figure 2. Fields in (b) are from Pearce et al. (1984).

Mountain and Lower St. Esprit plutons may owe their I-type features to their sources in the Late Precambrian complex of volcanic arcs which comprise the Mira Terrane (Barr et al., 1991). Melting may have resulted from heating by mafic 
magmas generated by incipient crustal extension in an overall strike-slip regime, although direct evidence for coeval mafic magmatism has not been recognized in the Mira Terrane.

Similarities in age, petrology, and mineralization are evident between the plutons of this study and the Ackley Granite of Newfoundland (e.g., Tuach et al., 1986; Tuach, 1987; Kontak et al., 1988). The Ackley Granite is a much larger and more complex intrusion that apparently evolved from I-type to A-type, mainly during the Devonian but covering a period of at least $50 \mathrm{Ma}$ (Kontak et al., 1988). Dating of the plutons of the present study is not precise enough to know whether or not an equivalent progression in chemical character is represented by the Lower St. Esprit through Gillis Mountain/Deep Cove/Blue Mountain plutons to Salmon River rhyolite porphyry. The protracted history and petrological diversity of the Ackley Granite may be related to its location at a major fault marking a terrane boundary. Small plutons analogous to those in southeastern Cape Breton Island are not reported to occur within the Avalon terrane in Newfoundland (Williams et al., 1989).

\section{Summary and Conclusions}

Given their spatial proximity, geochemical similarities to I-type granite, and $\mathrm{Cu}$-Mo dominant, polymetallic mineralization, the Gillis Mountain, Deep Cove, and Blue Mountain high-level intrusions were probably co-genetic and possibly co-magmatic. Together, they represent an important metallogenic episode in southeastern Cape Breton Island in the Middle to Late Devonian and possibly later. The relationship of the Lower St. Esprit granite/granodiorite and Salmon River rhyolite porphyry to the other intrusions is less clear. Lower St. Esprit pluton appears to have been derived from a less evolved magma, with geochemical features transitional between those of M-type and I-type granites, that was emplaced at a somewhat deeper level. In contrast, Salmon River pluton appears to represent a highly evolved magma. It has some features of an A-type granite, and was emplaced as a high-level laccolithic sheet. On a regional scale, the Devonian plutons in southeastern Cape Breton Island are part of a significant episode of post-tectonic, high-level plutonism that occurred widely in the northern Appalachian Orogen during the Middle to Late Devonian. Petrochemical characteristics of plutons formed during this time may reflect in part the nature of the tectonostratigraphic terrane in which they formed (e.g., Barr, 1990).

\section{Acknowledgements}

We thank the former graduate students of Acadia University referenced below whose work forms the basis of this review. Financial support for these earlier studies and the present work has been provided mainly by Natural Sciences and Engineering Research Council of Canada operating grants to SMB, with contributions from the Nova Scotia Department of Natural Resources (formerly Mines and Energy) and the
Geological Survey of Canada through Canada-Nova Scotia Mineral Development Agreements. We are grateful to reviewers M.A. MacDonald and W.D. Sinclair, and editor D.J. Kontak, whose comments on the original manuscript led to an improved final version.

BARR, S.M. 1990. Granitoid rocks and terrane characterization: an example from the northern Appalachian orogen. Geological Journal, 25, pp. 295-304.

BARR, S.M. and MACDONALD, A.S. 1985. Diverse polymetallic mineralization associated with Devonian granitoid plutons, southeastern Cape Breton Island, Nova Scotia. In GraniteRelated Mineral Deposits. Edited by R.P. Taylor and D.F. Strong. Extended abstracts of papers presented at the CIM conference, September 15-17, Halifax, Nova Scotia, pp. 2124.

Barr, S.M. and O'Beirne, A.M. 1979. Petrology of the Gillis Mountain pluton, Cape Breton Island, Nova Scotia. Canadian Journal of Earth Sciences, 18, pp. 395-404.

BARR, S.M. and PRIDE, C.R. 1986. Petrogenesis of two contrasting Devonian granitic plutons, Cape Breton Island, Nova Scotia. Canadian Mineralogist, 24, pp. 137-146.

BARR, S.M. and RAESIDE, R.P. 1989. Tectonostratigraphic terranes in Cape Breton Island, Nova Scotia: implications for the configuration of the northern Appalachian Orogen. Geology, 17 , pp. 822-825.

BARr, S.M., O'Reilly, G.A., and O'Beirne, A.M. 1982. Geology and geochemistry of selected granitoid plutons of Cape Breton Island. Nova Scotia Department of Mines and Energy, Paper 82-1, $176 \mathrm{p}$.

Barr, S.M., Sangster, D.F., and Cormier, R.F. 1984. Petrology of early Cambrian and Devono-Carboniferous intrusions in the Loch Lomond Complex, southeastern Cape Breton Island, Nova Scotia. In Current Research, Part A, Geological Survey of Canada, Paper 84-1A, pp. 203-211.

Barr, S.M., Macdonald, A.S., and White, C.E. 1988. The Fourchu Group and associated granitoid rocks, Coxheath Hills, East Bay Hills, and southwestern Stirling and Coastal belts, southeastern Cape Breton Island, Nova Scotia. Geological Survey of Canada, Open File 1759.

Barr, S.M., Macdonald, A.S., and White, C.E. 1989. The Fourchu Group and associated granitoid rocks, Stirling and Coastal belts, southeastern Cape Breton Island. Geological Survey of Canada, Open File 1988.

Barr, S.M., Bevier, M.L., White, C.E., and Macdonald, A.S. 1991. Geochronology and petrochemistry of volcanic and plutonic rocks, SE Cape Breton Island (Avalon Terrane), Nova Scotia. Geological Association of Canada - Mineralogical Association of Canada, Program with Abstracts, 16, p. A7.

Barr, S.M., White, C.E., and Macdonald, A.S. 1992. Revision of upper Precambrian - Cambrian stratigraphy, southeastern Cape Breton Island, Nova Scotia. In Current Research, Part D, Geological Survey of Canada, Paper 92-1D, pp. 21-26.

Cawthorne, R.G., Strong, D.F., and Brown, P.A. 1976. Otigin of corundum-normative intrusive and extrusive magmas. Nature, 259, pp. 102-104.

Chappell, B.W. and White, A.J.R. 1974. Two contrasting granite types. Pacific Geology, 8, pp. 173-174.

Cormier, R.F. 1972. Radiometric ages of granitic rocks, Cape Breton Island, Nova Scotia. Canadian Journal of Earth Sciences, 9, pp. 1074-1086. 
1979. Rubidium/strontium isochron ages of Nova Scotian granitoid plutons. Nova Scotia Department of Mines and Energy, Report 79-1, pp. 143-147.

Dennis, F.A.R. 1988. Petrology and mineralization of the Deep Cove Pluton, Gabarus Bay, Cape Breton Island, Nova Scotia. M.Sc. thesis, Acadia University, Wolfville, Nova Scotia, 209 p.

DoIg, R., MURPHY, J.B., and BARR, S.M. 1990. Archean and Early Proterozoic detrital zircon in Paleozoic silicic rocks of Cape Breton Island and Cobequid Highlands, Nova Scotia: preliminary results. In Program and Summaries, 14th Annual Open House and Review of Activities. Nova Scotia Department of Mines and Energy, Report 90-3, p. 37.

Einaudi, M.T., Meinert, L.D., and Newberry, R.J. 1981. Skarn deposits. Economic Geology, 75th Anniversary Volume, pp. 317-391.

Ervine, W.B. 1981. A geologic evaluation of the Deep CoveEagle Head area Gabarus Bay, Cape Breton Island, Nova Scotia. Nova Scotia Department of Mines and Energy, Assessment Report 11F/16A 35-C-41.

Evenson, N.M., Hamilton, P.J., and Onions, R.K. 1978. Rareearth element abundances in chondritic meteorites. Geochimica Cosmochimica Acta, 42, pp. 1199-1212.

Felderhof, G.W. 1978. Barite, celestite and fluorite in Nova Scotia. Nova Scotia Department of Mines and Energy, Bulletin 4, $463 \mathrm{p}$.

Gibling, M.R., Boehner, R.C., and Rust, B.R. 1987. The Sydney basin of Atlantic Canada: an Upper Paleozoic strike-slip basin in a collisional setting. In Sedimentary Basins and Basin-forming Mechanisms. Edited by C. Beaumont and A.J. Tankard. Canadian Society of Petroleum Geologists, Memoir 12. pp. 269-285.

Hollister, V.F., Potter, R.R., and Barker, A.L. 1974. Porphyry-type deposits of the Appalachian Orogen. Economic Geology, 69, pp. 618-629.

JENNER, J.A., LONGERICH, H.P., JACKSON, S.E., and Fryer, B.J. 1990. ICP-MS - a powerful tool for high-precision traceelement analysis in Earth sciences: evidence from analysis of selected U.S.G.S. reference samples. Chemical Geology, 83, pp. 133-150.

KeppIE, J.D. 1979. Geological map of Nova Scotia. Nova Scotia Department of Mines and Energy.

1989. Northern Appalachian terranes and their accretionary history. Geological Society of America, Special Paper 230. pp. 159-192.

KeppIE, J.D. and SMITh, P.K. 1978. Compilation of isotopic age data of Nova Scotia. Nova Scotia Department of Mines and Energy, Report 78-4.

Kirkham, R.V. and Soregaroli, A.E. 1975. Preliminary assessment of porphyry deposits in the Canadian Appalachians. Geological Survey of Canada, Paper 75-1, pp. 249-251.

Kontak, D.J., Tuach, J., Strong, D.F., Archibald, D.A., and FARRAR, E. 1988. Plutonic and hydrothermal events in the Ackley Granite, southeast Newfoundland, as indicated by total-fusion ${ }^{40} \mathrm{Ar} /{ }^{39} \mathrm{Ar}$ geochronology. Canadian Journal of Earth Sciences, 25, pp. 1151-1160.

Macdonald, A.S. 1989. Metallogenic studies, southeastern Cape Breton Island. Nova Scotia Department of Mines and Energy. Paper 89-1, 99 p.

MACDONALD, A.S and BARR, S.M. In press. The Blue Mountain polymetallic skarn and associated porphyry dykes, southeastern Cape Breton Island, Nova Scotia. In Metallogenic Studies in Nov a Scotia, Volume 2. Edited by A.L. Sangster. Geological Survey of Canada Paper.

McMullin, D.W. 1984. The Loch Lomond plutonic complex, Cape Breton Island, Nova Scotia. M.Sc. thesis, Acadia University, Wolfville, Nova Scotia, 241 p.

O'Beirne, A.M. 1979. Geology of the Gillis Mountain pluton, Cape Breton Island. M.Sc. thesis, Acadia University, Wolfville, Nova Scotia, 168 p.

O'Reilly, G.A. 1977. Field relations and mineral potential of the granitoid rocks of southeast Cape Breton Island. In Report of Activities, 1976. Nova Scotia Department of Mines, Report 77-1, pp. 81-87.

Pearce, J.A., Harris, N.B.W., and Tindle, A.G. 1984. Trace element discrimination diagrams for the tectonic interpretation of granitic rocks. Journal Petrology, 25, pp. 956-983.

Pitcher, W.S. 1987. Granite types and tectonic environment. In Mountain Building Processes. Edited by K.J. Hsu. Academic Press, London, pp. 19-40.

SAngster, D.F. and Vaillancourt, P.D. 1990. Geology of the Yava sandstone-lead deposit, Cape Breton Island, Nova Scotia, Canada. In Mineral Deposit Studies in Nova Scotia, Volume 1. Edited by A.L. Sangster. Geological Survey of Canada, Paper 90-8, pp. 203-244.

Stockmal, G.S., Colman-Sadd, S.P., Keen, C.E., Marillier, F., O'Brien, S.J., and Quinlan, G.M. 1990. Deep seismic structure and plate tectonic evolution of the Canadian Appalachians. Tectonics, 9, pp. 45-62.

TUACH, J. 1987. The Ackley high-silica magmatic/metallogenic system and associated post-tectonic granites, southwest Newfoundland. Ph.D. thesis, Memorial University of Newfoundland, St. John's, Newfoundland.

Tuach, J., Davenport, P.H., Dickson, W.L., and Strong, D.F. 1986. Geochemical trends in the Ackley granite, southeast Newfoundland: their relevance to magmatic-metallogenic processes in high-silica granitoid systems. Canadian Journal of Earth Sciences, 23, pp. 747-765.

Vaillancourt, P.D. and Sangster, D.F. 1984. Petrology of mineralization at the Yava sandstone-lead deposit, Nova Scotia. In Current Research, Part A, Geological Survey of Canada, Paper 84-1A, pp. 345-352.

Weeks, F.J. 1954. Southeast Cape Breton Island, Nova Scotia. Geological Survey of Canada, Memoir 277, 112 p.

Whalen, J.B., Currie, K.L., and Chappell, B.W. 1987. A-type granites: geochemical characteristics, discrimination and petrogenesis. Contributions to Mineralogy and Petrology, 95, pp. 407-419.

White, A.J.R. and Chappell, B.W. 1983. Granitoid types and their distribution in the Lachlan Fold Belt, southeastern Australia. In Circum-Pacific plutonic terranes. Edited by J.A. Roddick. Geological Society of America, Memoir 159, pp. 21-34.

Williams, H., Dickson, W.L., Currie, K.L., Hayes, J.P., and TUACH, J. 1989. Preliminary report on a classification of Newfoundland granitic rocks and their relations to tectonostratigraphic zones and lower crustal blocks. In Current Research, Part B, Geological Survey of Canada, Paper 89-1B, pp. 47-53. 